\title{
Assessment of different cut-off values of the ELISA-Typhimurium for the discrimination of swine herds with Salmonella isolation
}

\author{
Avaliação de diferentes pontos de corte no teste de ELISA para \\ discriminação de lotes de suínos com isolamento de Salmonella sp
}

\author{
Jalusa Deon Kich ${ }^{1 *}$; Eduardo de Freitas Costa ${ }^{2}$; Nelise Juliane Triques ${ }^{2}$; \\ Mariana Nogueira ${ }^{2}$; Osmar Dalla Costa ${ }^{1}$; Arlei Coldebella ${ }^{1}$; \\ Aline $\mathrm{Kummer}^{3}$; Marisa Cardoso ${ }^{4}$
}

\begin{abstract}
Salmonella control programs require the classification of positive herds according with the prevalence of infected pigs. This must be based on diagnostic methods that are reliable, accurate and cost effective. Since serological methods fulfill most of these prerequisites, many countries have adopted indirect ELISA tests to discriminate herds, based on their seroprevalence. In view of that, an in-house indirect ELISA test (ELISA-Typhimurium) previously developed proved to be able to detect sera antibodies against the most prevalent serovars of Salmonella found in Brazilian pig farms. This study aimed to assess different cut-off values of the ELISA-Typhimurium in terms of their correlation with Salmonella isolation results at the herd level. Blood and mesenteric lymph node or rectal swabs were taken from 56 slaughter and 14 grower batches from different farms. Serum was tested using the ELISA-Typhimurium at different cut-off points (OD: 6.87\%-40\%). A total of 55 slaughter batches had at least one Salmonellapositive sample, and the within-herd prevalence was 64.9\% ( $\mathrm{SE} \pm 24.8)$. All 14-grower batches were negative on Salmonella isolation. The logistic regression demonstrated that at 20\% OD the ELISATyphimurium test is the best model to predict Salmonella isolation frequency at the herd level. At this cut-off point, the test may be a helpful tool for discriminating Salmonella infected herds.
\end{abstract}

Key words: Cut-off. ELISA. Salmonella detection. Serology. Swine.

\section{Resumo}

Os programas de controle de Salmonella requerem a classificação de rebanhos de acordo com a prevalência de suínos infectados. Isto deve ser baseado em métodos de diagnóstico confiáveis, acurados e econômicos. Como os métodos sorológicos atendem estes pré-requisitos, muitos países têm adotado o teste de ELISA indireto na discriminação dos rebanhos, baseado na soroprevalência. Em vista disto, um teste de ELISA indireto (ELISA-Typhimurium) previamente desenvolvido demonstrou ser capaz de detectar anticorpos contra os sorovares de Salmonella mais prevalentes em granjas de suínos no Brasil. O presente estudo objetivou testar diferentes pontos de corte do teste ELISA-Typhimurium em termos de sua correlação com os resultados de isolamento de Salmonella na granja. Sangue e linfonodos mesentéricos ou suabes fecais foram colhidos de suínos pertencentes a 56 lotes de abate e 14 lotes de

\footnotetext{
${ }^{1}$ Pesquisadores, EMBRAPA Suínos e Aves, Bairro Tamanduá, Concórdia, SC, Brasil. E-mail: jalusa.kich@embrapa.br; osmar. dallacosta@embrapa.br; arlei.coldebella@embrapa.br

2 Discentes, Curso de Mestrado do Programa de Pós-Graduação em Medicina Veterinária, Universidade Federal do Rio Grande do Sul, UFRGS, Porto Alegre, RS, Brasil.E-mail: eduardo.costa@ufrgs.br, nelise.triques@brf-br.com; mariana_nogueira@hotmail. com

${ }^{3}$ Discente do Curso Graduação em Medicina Veterinária, UFRGS, Porto Alegre, RS, Brasil. E-mail: alinekummer@yahoo.com.br

${ }^{4}$ Prof $^{\mathrm{a}}$, Departamento de Medicina Veterinária Preventiva, UFRGS, Porto Alegre, RS, Brasil. E-mail: mcardoso@ufrgs.br

* Author for correspondence
} 
crescimento em diferentes granjas. O soro foi testado no ELISA-Typhimurium em diferentes pontos de corte (DO: 6,87\%-40\%). Um total de 55 lotes de abate testados apresentaram pelo menos uma amostra com isolamento de Salmonella, e a prevalência intra-lote foi de $64,9 \%$ (EP $\pm 24,8)$. Todos os lotes de crescimento foram negativos no isolamento de Salmonella. A regressão logística demostrou que a DO20\% é o melhor modelo para predizer a frequência de isolamento de Salmonella em lotes de suínos. Nesse ponto de corte, o teste poderá ser uma ferramenta útil para discriminar lotes suínos infectados por Salmonella.

Palavras-chave: ELISA. Detecção de Salmonella. Ponto de corte. Sorologia. Suíno.

\section{Introduction}

Non-typhoidal salmonellosis is the most prevalent food-borne disease in Brazil, and pork has been involved in about $4.9 \%$ of human cases (BRASIL, 2013). Salmonella infection in swine herds has been demonstrated in Brazil (SCHWARZ et al., 2009), and a relatively high prevalence of Salmonella isolation has been found in pigs at slaughter, as well as in carcasses (KICH et al., 2011). These results demonstrate that control measures must be implemented on farms, in order to reduce the number Salmonella positive pigs delivered at slaughterhouses.

In recent years, Salmonella control programs in pigs have been a matter of discussion in terms of concentrating efforts at the pre-harvest or postharvest stage (ALBAN et al., 2012). Control at post-harvest was found to be more cost-effective (GOLDBACH; ALBAN, 2006). However, the association between Salmonella carcass prevalence and the seroprevalence in the source herd has also been demonstrated (BAPTISTA et al., 2010), highlighting that control at the herd level cannot be overlooked. Given that it will be economically unfeasible to apply strict measures to all herds engaged in a swine production system, those herds with a higher frequency of positive pigs should be prioritized, and every effort should be made to reduce the Salmonella transmission in those herds (ALBAN et al., 2012). The identification of herds, in turn, must be based on diagnostic methods that are reliable, accurate and cost effective. Since serological methods fulfill most of these prerequisites, many countries have adopted indirect ELISA tests to discriminate herds, based on their seroprevalence (MERLE et al., 2011; ALBAN et al., 2012).

In Brazil, an in-house indirect ELISA test (ELISA-Typhimurium) based on the $S$. Typhimurium lipopolysaccharide (LPS) was developed (KICH et al., 2007) and proved to be able to detect sera antibodies against the most prevalent serovars of Salmonella found in the Brazilian swine production system. However, the cut-off initially established (experimental cut off) for the test presents limitations in the discrimination of herds with high and low number of positive pigs on Salmonella isolation. Since one important step for planning a control program is to adapt the diagnostic tools in order to make it possible to discriminate among herds, this study aimed to assess different cut-off values of the ELISA-Typhimurium in terms of their correlation with Salmonella isolation results at the herd level.

\section{Materials and Methods}

Serum samples from 56 slaughter batches and 14 grower batches from different farms located in southern Brazil were included in this study. Samplings were performed between March and December of 2012. From each slaughter batch, blood samples $(n=24)$ were taken randomly at the bleeding step, and the same number of pigs were sampled for mesenteric lymph nodes at the evisceration step. Grower batches were sampled on the day of housing at the farm, and 56 pigs were individually sampled (blood and rectal swabs) in each batch. Blood samples were allowed to clot and serum was stored at $-20^{\circ} \mathrm{C}$. Feces and mesenteric lymph nodes were placed separately in sterile plastic bags and 
transported to the laboratory in a cooled container for analysis. The rectal swabs and $25 \mathrm{~g}$ of lymph nodes were submitted to the Salmonella isolation protocol (INTERNATIONAL ORGANIZATION FOR STANDARDIZATION, 2007), pre-enriched in 225 $\mathrm{ml}$ of buffered peptone water (BPW, Merck \& Co., Inc., Whitehouse Station, N.J., U.S.A.) for $24 \mathrm{~h}$ at $37^{\circ} \mathrm{C}$. The lymph node surface was decontaminated by flaming, and $25 \mathrm{~g}$ were taken aseptically and homogenized in a Stomacher (Interscience, St. Nom, France) for $1 \mathrm{~min}$. For the selective enrichment, $100 \mu \mathrm{l}$ and $1 \mathrm{ml}$ of pre-enriched broth were added to $9.9 \mathrm{ml}$ of Rappaport-Vassiliadis (RV, Merck \& Co., Inc.) and $9 \mathrm{ml}$ of Tetrathionate Müller Kauffmann broths (TMK, Difco Laboratories, Detroit, USA), respectively, which were then incubated for $24 \mathrm{~h}$ at $42^{\circ} \mathrm{C}$. Afterwards, a loopful of each enriched broth was streaked onto XyloseLysine-Tergitol 4 (XLT4, Difco) and BrilliantGreen Phenol Red Lactose Sucrose (BPLS, Merck) agars. The presumptive colonies were streaked onto Tryptic Soy Agar (TSA, Merck) and subjected to biochemical tests, including Lysine-Iron agar (LIA, Merck), Urea broth, Phenylalanine agar (Merck), Simmons citrate agar (Merck), $\beta$-galactosidase test (ONPG, Merck), and Triple Sugar-Iron agar (TSI, Merck). SIM Agar (Merck) was used to confirm the Salmonella suspected colonies. A slide agglutination test was performed using polyclonal Salmonella enterica antiserum (Probac Ltda., São Paulo, Brazil). Salmonella spp. isolates were serotyped by Kauffman and White classification scheme, based on surface antigens, at the National Reference Center, Instituto Oswaldo Cruz, Rio de Janeiro, Brazil.

Serum was used in the ELISA-Typhimurium test developed by Kich et al. (2007), which is based on the phenol extracted LPS of S. Typhimurium (strain BRMSA 1084). Briefly, sera samples were diluted (1:400) in PBS pH 7.4 containing $0.05 \%$ Tween 20 (PBS-T) with 1\% bovine serum albumin (PBSTA) and added in triplicate to the plates coated with the antigen $(1: 2,000)$. After incubation for 30 min at $37^{\circ} \mathrm{C}$, the plates were washed with PBS-T. In each well, $100 \mathrm{ml}$ of anti-pig IgG conjugated to horseradish peroxidase diluted 1:25,000 in PBS-TA was added. The plates were incubated for $1 \mathrm{~h}$ at $37^{\circ} \mathrm{C}$. After washing, the color reaction was developed using $100 \mathrm{ml}$ of substrate $\left(3.5 \mathrm{ml} \mathrm{H}_{2} \mathrm{O}_{2}, 230 \mathrm{ml} 10 \mathrm{~N}\right.$ $\mathrm{NaOH}$, and $10 \mathrm{ml}$ 3,39,5,59 tetramethyl-benzidine). After $15 \mathrm{~min}$ at room temperature, the reaction was stopped with $50 \mathrm{ml}$ of $2 \mathrm{M}$ sulphuric acid. The OD at $450 \mathrm{~nm}$ was assessed using a plate reader (Titertek Multiscan). Sample OD values were transformed to calibrated ODs using a linear regression equation for standard ODs on the actual plate versus mean reference ODs. Standard OD values correspond to the average of triplicate medians obtained for negative and positive (weak, medium and strong) serum pools. The ELISA experimental cut-off point was set at the OD average obtained for the negative control serum samples plus four standard deviations, and was set at OD 0.169 (KICH et al., 2007). The $\% O D$ for serum was calculated following the equation, where $\mathrm{NC}$ is the optical density of a reference negative sample; and PC is the optical density of a reference strong positive sample. The experimental cut-off was equivalent to OD6.87\%. In this study, all serum samples were tested at the cut-off OD $6.87 \%, 10 \% ; 20 \% ; 30 \%$ and $40 \%$.

A slaughter or grower batch was considered Salmonella-negative when none of the samples were positive in the Salmonella isolation protocol; batches were considered negative in the ELISATyphimurium when none of the serum samples at a given cut-off point were positive. The relative sensitivity (rSe) and relative specificity ( $\mathrm{rSp}$ ) of each cut-off point at the herd level were estimated by comparing results (positive/negative batch) obtained at each cut-off value with those obtained for the same batches by Salmonella isolation. The overall performance of the test at each cut-off point in comparisson to Salmonella isolation was estimated through Youden's index $J$ $=(r S e+r S p-1)$. 
For the best cut-off determination at herd level, logistic regression models were performed following the equation

$$
\operatorname{logit}\left(\frac{y}{n}\right)=B 0+B 1 * x \text {, }
$$

where $\mathbf{y}$ is the number of pigs with positive Salmonella sp. isolation, $\mathbf{n}$ is the number of pigs sampled and $\mathbf{x}$ is the serological result.

The likelihood-ratio goodness of fit test statistic $\left[\Delta \mathbf{G}^{2}=(-2 \mathrm{LogL}\right.$ reduced model $-(-2 \mathrm{Log} L$ full model $)]$ under the hypothesis $\mathrm{H}_{0}$ : reduced model is true vs. $\mathrm{H}_{\mathrm{A}}$ : full model is true following a chi-square distribution and k-1 (full model) degrees of freedom (DOMÍNGUEZ-ALMENDROSA et al., 2011) was performed by means of a logistic regression, using the Williams method to correct the overdispersion in the PROC LOGISTIC of SAS (2012). Then, the Spearman Rho correlation coefficient $(\rho)$ between herd prevalence (according to the frequency of Salmonella isolation) and seroprevalence was evaluated at the best cut-off. All analyses were performed using the software SAS version 9.2 for Windows (Copyright (C) 2012 SAS Institute Inc.).

\section{Results and Discussion}

In line with previous studies conducted in Brazil (SCHWARZ et al., 2009; $\mathrm{KICH}$ et al., 2011), bacteriological testing showed that 55 out of 56 slaughter batches had at least one Salmonellapositive result in mesenteric lymph nodes. On the other hand, all 14-grower batches were negative in the bacteriological testing of feces samples. The within-heard prevalence of pigs with Salmonella isolation in positive herds was $64.9 \%$ ( $\mathrm{SE} \pm 24.8$ ). Among the 855 slaughter pigs that were Salmonellapositive, $85.1 \%$ were infected with serovars that presented somatic antigens in common with those of the ELISA-Typhimurium (Table 1). Salmonella Typhimurium, Derby and Panama were the most prevalent at the individual as well as the herd level.
The predominance of these serovars was consistent with previous studies, which also found Salmonella serogroup O:4 (B) to be the most prevalent in Brazilian swine herds (SCHWARZ et al., 2009; $\mathrm{KICH}$ et al., 2011). Therefore, it was expected that the ELISA-Typhimurium would be able to detect antibodies in most of the positive herds, if the infection occurred before the period needed for seroconversion.

In fact, serological testing was able to detect at least one seropositive animal in $98.2 \%(54 / 55)$ Salmonella-positive herds at three of the tested cutoff values, namely OD $6.87 \%$, OD $10 \%$ and OD $20 \%$ (Table 2). At the aforementioned cut-offs the relative sensitivity of the test was quite high (0.98), considering Salmonella isolation as the reference. In the single seronegative herd that presented Salmonella isolation from pigs at slaughter, two serovars ( $S$. Panama and $S$. Senftenberg), theoretically detectable by the ELISA-Typhimurium (Table 1), were identified. However, in our study another 24 seropositive herds were infected with $S$. Panama, and in two of them, this was the only serovar identified. Therefore, we speculate that the sampling of animals in this herd may have occurred after the time needed to detect seroconversion.

A large difference in the relative specificity presented by the test at different cut-off points was observed (Table 2). At the experimental cut-off point (OD 6.87\%), in the majority of seropositive herds Salmonella was not isolated. Better performance of the test in terms of rSe, rSp and Youden's index was observed at cut-off points OD 10\% and OD 20\%. This means that at these cut-offs the test was able to assign the seropositive herds more correctly in relation to their Salmonella isolation results.

The regression model, which was constructed to evaluate the correlation between the seroprevalence in relation to the apparent prevalence of Salmonella isolation within herds, demonstrated the greatest deviance ratio $\left(\Delta G^{2}=47.8, p\right.$-value $\left.<0.001\right)$ at the cut-off OD 20\%. This means that at $20 \%$ OD 
the ELISA-Typhimurium test is the best model to predict Salmonella isolation frequency at the herd level. At this cut-off point the Spearman's correlation coefficient between within-herd seroprevalence and apparent Salmonella isolation prevalence was significant and moderate $(=0.6 ; P<0.001)$.

Table 1. Distribution of Salmonella serovars detected in the 55 positive pig slaughter batches, according to the presence of common antigens in the ELISA-Typhimurium.

\begin{tabular}{|c|c|c|}
\hline Serovar & $\begin{array}{c}\text { Number of } \\
\text { infected herds }\end{array}$ & $\begin{array}{c}\text { Number of } \\
\text { infected pigs }\end{array}$ \\
\hline \multicolumn{3}{|c|}{ With at least one common somatic antigen with the test's antigenic formulae ${ }^{a}$} \\
\hline Typhimurium & 35 & 228 \\
\hline Derby & 30 & 214 \\
\hline Panama & 25 & 148 \\
\hline Bredeney & 4 & 45 \\
\hline Agona & 5 & 37 \\
\hline $0: 4,5$ & 13 & 37 \\
\hline Senftenberg & 6 & 17 \\
\hline Enteritidis & 2 & 2 \\
\hline Total infected pigs $(\%)$ & - & $728(85.1 \%)$ \\
\hline \multicolumn{3}{|c|}{ Without any common somatic antigen with the test's antigenic formulae } \\
\hline Infantis & 15 & 85 \\
\hline Cerro & 2 & 16 \\
\hline Anatum & 3 & 8 \\
\hline $\mathrm{O}: 3,10$ & 2 & 6 \\
\hline Salmonella rough & 5 & 7 \\
\hline Give & 1 & 1 \\
\hline Lexington & 1 & 1 \\
\hline Rissen & 1 & 1 \\
\hline $0: 6,7$ & 1 & 1 \\
\hline $\mathrm{O}: 13,23$ & 1 & 1 \\
\hline Total infected pigs (\%) & - & $127(14.9 \%)$ \\
\hline
\end{tabular}

${ }^{\mathrm{a} A t}$ least one somatic antigen in common with the antigenic formulae of the ELISA-Typhimurium $(\mathrm{O}: 1,4,5,12)$.

A moderate correlation between seroprevalence and the proportion of positive pooled faecal samples was also found by Lo Fo Wong et al. (2004), while other studies reported a low correlation between serology and Salmonella isolation at the pig or herd level (FUNK et al., 2005; VICO et al., 2010). The fact that bacteriological detection and serology measure two different infection stages explains the moderate correlation between tests. Salmonella isolation from mesenteric lymph node samples is indicative of true infection of individual pigs at slaughter (VICO et al.,
2010). However, transmission may have occurred either on farm or during the transportation and at the lairage (HURD et al., 2002). Thus, Salmonella isolation is a valuable and indispensable approach to monitoring the hazard of carcass contamination. On the other hand, in countries that conducted a monitoring program in parallel with measures focused on the abattoir, serology has been adopted with the main purpose of classifying herds according to the interventions needed to control Salmonella on farm (ALBAN et al., 2012). 
Table 2. Relative sensitivity (rSe) and specificity (rSp) and Youden's index ( $J$ ) regarding Salmonella isolation from lymph nodes or feces at herd level for different cut-off points of the ELISA-Typhimurium.

\begin{tabular}{|c|c|c|c|c|c|c|}
\hline \multirow{2}{*}{\multicolumn{2}{|c|}{ Cut-off }} & \multicolumn{5}{|c|}{ Salmonella Isolation } \\
\hline & & Positive* & Negative & $\mathrm{rSe}^{\mathrm{a}}$ & $\mathrm{rSp}^{\mathrm{a}}$ & $J^{b}$ \\
\hline \multicolumn{7}{|c|}{$6.87 \%$} \\
\hline & + & 54 & 12 & $\begin{array}{c}0.98 \\
(0.95-1)\end{array}$ & $\begin{array}{c}0.2 \\
(0.1-0.29)\end{array}$ & 0.18 \\
\hline & - & 1 & 3 & & & \\
\hline \multicolumn{7}{|l|}{$10 \%$} \\
\hline & + & 54 & 1 & $\begin{array}{c}0.98 \\
(0.95-1)\end{array}$ & $\begin{array}{c}0.93 \\
(0.87-0.99)\end{array}$ & 0.91 \\
\hline & - & 1 & 14 & & & \\
\hline \multicolumn{7}{|l|}{$20 \%$} \\
\hline & + & 54 & 1 & $\begin{array}{c}0.98 \\
(0.95-1)\end{array}$ & $\begin{array}{c}0.93 \\
(0.87-0.99)\end{array}$ & 0.91 \\
\hline & - & 1 & 14 & & & \\
\hline \multicolumn{7}{|l|}{$30 \%$} \\
\hline & + & 53 & 1 & $\begin{array}{c}0.96 \\
(0.91-1)\end{array}$ & $\begin{array}{c}0.93 \\
(0.87-0.99)\end{array}$ & 0.89 \\
\hline & - & 2 & 14 & & & \\
\hline \multicolumn{7}{|l|}{$40 \%$} \\
\hline & + & 52 & 1 & $\begin{array}{c}0.94 \\
(0.89-0.99)\end{array}$ & $\begin{array}{c}0.93 \\
(0.87-0.99)\end{array}$ & 0.87 \\
\hline & - & 3 & 14 & & & \\
\hline Total & & 55 & 15 & & & \\
\hline
\end{tabular}

*A herd was considered positive when at least one sample resulted in Salmonella isolation. A herd was considered seropositive when at least one serum sample was positive at the given cut-off point.

aIn brackets the 95\% Confidence Interval

Salmonella eradication in all finishing swine herds is not a feasible target; therefore, control measures should aim at diminishing the frequency of positive pigs delivered to slaughter. In a scenario, in which slaughter batches present a low number of pigs carrying Salmonella, effective Good Manufacturing Practices and HACCP programs in force at slaughterhouses will be able to control contamination of carcasses and pork. Therefore, pre-harvest intervention programs implemented in vertically integrated pig suppliers should be started in farms with a higher prevalence of Salmonella positive pigs. Even considering the limitations of associating serology and Salmonella isolation, the adoption of the cut-off OD $20 \%$ for the ELISA-
Typhimurium achieved the best correlation with the Salmonella prevalence on farm and may be a helpful tool for identifying high-risk herds.

\section{Conclusion}

The ELISA-Typhimurium test at the cut-off OD $20 \%$ presents the best correlation with the prevalence of Salmonella isolation at the herd level.

\section{References}

ALBAN, L.; BAPTISTA, F. M.; MØGELMOSEA, B.; SØRENSENA, L. L.; CHRISTENSENC, H.; AABOD, S.; DAHLA, J. Salmonella surveillance and control for 
finisher pigs and pork in Denmark - a case study. Food Research International, Toronto, v. 45, n. 2, p. 656-665, 2012. Available at: <http://www.sciencedirect.com/ science/article/pii/S0963996911001529>. Accessed at:16 jun. 2014.

BAPTISTA, F. M.; DAHL, J.; NIELSEN, L. R. Factors influencing Salmonella carcass prevalence in Danish pig abattoirs. Preventive Veterinary Medicine, St. Louis, v. 95, n. 3-4, p. 231-238, 2010. Available at: $<$ http://www.sciencedirect.com/science/article/pii/ S0167587710001297>. Accessed at:16 jun. 2014.

BRASIL. Ministério da Saúde. Secretaria de Vigilância em Saúde. Vigilância epidemiológica de doenças transmitidas por alimentos. Brasília, DF, 2013. Disponível em: <http://camara.leg.br>. Acesso em: 14 mar. 2014.

DOMÍNGUEZ-ALMENDROSA, S. B. P. N.; BENÍTEZ-PAREJO, N.; GONZALES-RAMIREZ, A. R. Logistic regression models. Allergologia et Immunopathologia, Madrid, v. 39, n. 5, p. 295-305, 2011. Available at: <http://www.sciencedirect.com/science/ journal/03010546/39/5>. Accessed at: 16 jun. 2014.

FUNK, J. A.; HARRIS, I. T.; DAVIES, P. R. Comparison of fecal culture and Danish Mix-ELISA for determination of Salmonella enterica subsp enterica prevalence in growing swine. Veteterinary Microbiology, Washington, v. 107, n. 1-2, p. 115-126, 2005. Available at: <http://www.sciencedirect.com/science/article/pii/ S0378113505000192>. Accessed at: 16 jun. 2014.

GOLDBACH, S. G.;ALBAN, L. A cost-benefit analysis of Salmonella-control strategies in Danish pork production. Preventive Veterinary Medicine, St. Louis, v. 77, n. 1-2, p. 1-14, 2006. Available at: <http://www.sciencedirect. com/science/article/pii/S0167587706001450>. Accessed at: 16 jun. 2014.

HURD, H. S.; MCKEAN, J. D.; GRIFFITH, R. W.; WESLEY, I. V.; ROSTAGNO, M. H. Salmonella enterica infections in market swine with and without transport and holding. Applied and Evironmental Microbiology, Washington, v. 68, n. 5, p. 2376-2381, 2002. Available at: $<$ http://aem.asm.org/content/68/5/2376.long >. Accessed at: 16 jun. 2014.

INTERNATIONAL ORGANIZATION FOR STANDARDIZATION - ISO. Microbiology of food and animal feeding stuffs: Horizontal method for the detection of Salmonella spp. Amendment 1: anex D: detection of Salmonella spp. in animal faeces and in environmental samples from the primary production stage. 4. ed. Geneva: ISO, 2007. 38 p.

KICH，J. D.; COLDEBELLA, A.; MORES, N.; NOGUEIRA, M. G.; CARDOSO, M.; FRATAMICO, P.
M.; CALL, J. E.; FEDORKA-CRAY, P.; LUCHANSKY, J. B. Prevalence, distribution, and molecular characterization of Salmonella recovered from swine finishing herds and a slaughter facility in Santa Catarina, Brazil. International Journal of Food Microbiology, Torino, v. 151, n. 3, p. 307-313, 2011. Available at: $<$ http://www.sciencedirect.com/science/article/pii/ S0168160511005757>. Accessed at: 16 jun. 2014.

KICH， J. D.; SCHWARZ, P.; SILVA, L. E.; COLDEBELlA, A.; PIFFER, I. A.; VIZZOTO, R.; CARDOSO, M. Development and application of an enzyme-linked immunosorbent assay to detect antibodies against prevalent Salmonella serovars in swine in southern Brazil. Journal of Veterinary Diagnostic Investigation, Davis, v. 19 , n. 5, p. 510-517, 2007. Available at: $<$ http:// vdi.sagepub.com/content/19/5/510.long>. Accessed at: 16 jun. 2014.

MERLE, R.; KÖSTERS, S.; MAY, T.; PORTSCH, U.; BLAHA, T.; KREIENBROCK, L. Serological Salmonella monitoring in German pig herds: results of the years 2003-2008. Preventive Veterinary Medicine, St. Louis, v. 99, n. 2-4, p. 229-233, 2011. Available at: $\quad<\mathrm{http}: / /$ www.sciencedirect.com/science/article/pii/ S0167587711000389>. Accessed at: 16 jun. 2014.

LO FO WONG, D. M. A.; DAHL, J.; WINGSTRAND, A.; VAN DER WOLF, P. J.; VON ALTROCK, A.; THORBERG, B. M. A European longitudinal study in Salmonella seronegative- and seropositive-classified finishing pig herds. Epidemiology and Infection, Cambridge, v. 132, n. 5, p. 903-914, 2004. Available at: $\quad<$ http://www.ncbi.nlm.nih.gov/pmc/articles/ PMC2870178/>. Accessed at: 16 jun. 2014.

SAS. SAS/STAT ${ }^{\circledR} 12.1$ : user's guide. Cary: SAS Institute Inc, 2012.

SCHWARZ, P.; CALVEIRA, J.; SELLA, A. B.; BESSA, M. C.; BARCELOS, D. N. E. S. Salmonella enterica: isolamento e soroprevalência em suínos abatidos no Rio Grande do Sul. Arquivo Brasileiro de Medicina Veterinária e Zootecnia, Belo Horizonte, v. 61, n. 5, p. 1028-1034, 2009. Disponível em: <http://www.scielo.br/scielo. php?pid=S0102-09352009000500003\&script $=$ sci arttext>. Acesso em: 16 jun. 2014.

VICO, J. P.; ENGEL, B.; BUIST, W. G.; MAINARJAIME, R. C. Evaluation of three commercial enzymelinked immunosobent assays for the detection of antibodies against Salmonella spp. in meat juice from finishing pigs in Spain. Zoonoses and Public Health, Berlin, v. 57, p. 107-114, 2010. Supplement 1. Available at: <http://onlinelibrary.wiley.com/enhanced/ doi/10.1111/j.1863-2378.2010.01364.x/?isReporting Done $=$ true $>$. Accessed at: 16 jun. 2014. 
